Minister to constitute a challenge to the State, particularly since such memorials were to be held in honour only of the 'very greatest' Germans. The circular consequently concludes by forbidding all officials and all other members of staffs or institutions under the Ministry from attending the ceremony. It is difficult for scientific workers outside Germany to understand why a Minister of State should prohibit the commemoration of the great services rendered to that country and to the world by Haber, or what must be the feelings of the members of the societies concerned with the organisation of the proposed ceremony. Chemists and physicists throughout the scientific world acknowledge Haber's work as epochmaking, and Germany should be proud to cherish his memory. Truly in his case the Prussian Minister of Education now makes it clear that, officially, "A prophet is not without honour, save in his own country and in his own house".

\section{Intensive Farming and Security of Tenure}

THE Metropolitan Water Board is promoting a Bill in the present session of Parliament to acquire the Holly Lodge Farm, Walton-on-Thames, owned by Mr. A. F. Secrett, for the purpose of making a storage reservoir. Mr. Secrett is well known in the horticultural world as one of the leading growers of vegetable produce for market. $\mathrm{He}$ has been particularly prominent in developing the growing of early vegetables, winter salading, etc., hither to almost wholly supplied by French and other continental growers, and by his willingness to impart his knowledge of the management of these special crops, he has contributed more than anyone else to provide the home market with these products. The farm consists of 187 acres, of which 165 are now in intensive cultivation. One acre is under glass, three acres are under frames for early lettuce, etc. The seakale beds, traversed by an underground hotwater system, extend to about $\frac{1}{8}$ acre. The whole farm has been redrained so as to lower the winter water table 4-6 ft. below the surface. The irrigation system, with its own well and pumps, covers 125 acres, requiring $2 \frac{1}{2}$ miles of pipes. No other agricultural enterprise in Great Britain of this magnitude can show an equal intensity of cultivation; for example, a capitalisation of $£ 81$ per acre (exclusive of land), an output of $£ 142$ per acre, a wage bill of $£ 62$ per acre. No less than 10,000 tons of dung have been brought on to the farm for this year. It is noteworthy that Mr. Secrett, as a pioneer in his special business, has always been willing to instruct others; at the present time he has taken on fourteen young men to gain experience of his methods. They pay no premium and receive the ordinary wages; once each week Mr. Secrett lectures to them and explains his procedure.

The destruction of this business could not adequately be met by even the high compensation which Mr. Secrett might obtain. The site is a special one selected by Mr. Secrett after long search; it would be extremely difficult, indeed it might be impossible, to obtain an equivalent piece of land, which even then would require some years to equip and bring to a similar pitch of fertility. Doubtless very careful consideration has been given to the selection of this site for a reservoir, but it is difficult to suppose that no alternative exists. Mr. Secrett's farm stands pre-eminent as an example of the productive enterprise which the Government's agricultural policy is trying to foster, and of exceptional employment upon the land; under nothing short of absolute necessity should it be allowed to be submerged. Had the farm been a factory employing a hundred workmen and engaged in some new process, the Metropolitan Water Board would have thought twice about disturbing it. Yet it is a simple matter to rebuild a factory compared with the difficulty of finding a site and the time required to bring it into condition in order to replace the outfit represented by Holly Lodge Farm.

\section{Aboriginal Reserves in Australia}

Tre attention of the public in Australia has again been directed to the urgent problem of the aborigines and their reserves. On this occasion the method employed to secure its consideration has been unique. According to a dispatch from the Melbourne correspondent of The Times, which appeared in the issue of January 24, a deputation of ten full-blooded aborigines waited upon Mr. Paterson, the Minister of the Interior, to urge, among other matters, the establishment of a Federal Department of Native Affairs, under a sympathetic administrator such as Sir Hubert Murray, the present Lieut.-Governor of Papua, and the institution of an advisory council, which would include social, anthropological, medical and educational experts. The spokesman of the deputation directed attention to the serious economic situation now arising among the aborigines. $\mathrm{He}$ pointed out that they are being driven into barren wastes in which it is impossible for them to live. $\mathrm{He}$ also pledged the aborigines as Commonwealth citizens, believing that the British Empire stands for justice, order and freedom, to maintain their heritage handed down to them by the Creator, but suggesting in what followed that present conditions were not favourable to that end. This is a somewhat surprising, but none the less significant, indication of recent developments in the movement for the improvement of the lot of the aborigines. It is probable, and, in fact, certain that the Australian public generally is not very fully informed of conditions of life among the aborigines. The mere size of the reserves has tended to obscure the relation to the area requisite for subsistence to the mode of subsistence. It is not realised that a considerable range of land is needed for the support of even small groups of food gatherers such as those found among the Australian aborigines. The formation of a Department of Aboriginal Affairs, of which the consideration is promised by Mr. Paterson at the next conference of Premiers, would ensure a more carefully reasoned control of aboriginal territory in relation to their needs and mode of life. 